Article

\title{
Assessing Firm Readiness to Adopt Cluster-Based Innovative Projects: A Segmentation Analysis
}

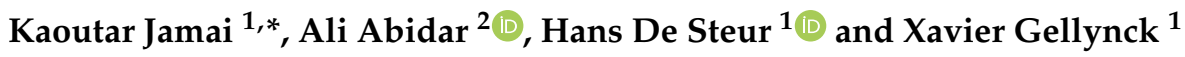 \\ 1 Department of Agricultural Economics, Ghent University, Coupure Links 653, 9000 Ghent, Belgium; \\ hans.desteur@UGent.be (H.D.S.); xavier.gellynck@UGent.be (X.G.) \\ 2 Department of Rural Development Engineering, National School of Agriculture, Meknes, km. 10, \\ Route Haj Kaddour, B.P. S/40, Meknes 50001, Morocco; aabidar@enameknes.ac.ma \\ * Correspondence: Kaoutar.jamai@UGent.be
}

Citation: Jamai, K.; Abidar, A.; De Steur, H.; Gellynck, X. Assessing Firm Readiness to Adopt Cluster-Based Innovative Projects: A Segmentation Analysis. Sustainability 2022, 14, 947. https://doi.org/10.3390/su14020947

Academic Editors

Konstadinos Mattas, George

Baourakis and Stefanos A. Nastis

Received: 6 December 2021

Accepted: 11 January 2022

Published: 14 January 2022

Publisher's Note: MDPI stays neutral with regard to jurisdictional claims in published maps and institutional affiliations.

Copyright: (C) 2022 by the authors. Licensee MDPI, Basel, Switzerland. This article is an open access article distributed under the terms and conditions of the Creative Commons Attribution (CC BY) license (https:// creativecommons.org/licenses/by/ $4.0 /)$.

\begin{abstract}
As innovation has garnered substantial attention on corporate success and sustainability, organizations must evaluate internal contexts to determine potential innovative practices and benefits. Firms need to investigate the determining factors of innovation preparedness as organizational innovation practices are catalyzed through internal elements. This study evaluates small and medium firms' readiness to adopt and execute collaborative innovative projects within a future cluster and its impacts on organizational advantages, intentions, and attributes. Thereby, three dimensions were considered in examining organizational preparedness, namely, climate, culture, and motivation A total of 70 firms operating in the labeled agri-food sector in Morocco were interviewed and homogenously classified using integrated hierarchical and non-hierarchical algorithms, following a segmentation approach. Three segments were identified, stressing the degree of organizational readiness to undertake innovative projects within future service clusters. The segments varied according to the firm's sub-sector, experience, and resources. Considering the association of readiness with benefits and practical aims, the results broaden firm preparedness understanding to adopt innovative projects. The results also illustrate the relevance of adapting both innovative and beneficial project arrangements for firms with minor to moderate experience while addressing current issues across different segments.
\end{abstract}

Keywords: cluster; food industry; innovative projects; labeled products; organizational readiness; segmentation approach; SME

\section{Introduction}

Although innovation reflects specific financial benefits as a key determinant of organizational success and sustainability [1,2], this concept is also inextricably connected to ambiguities and intricate work management $[3,4]$. As such, current versatile and innovative projects induced organizational competitiveness towards innovation for sustainable and profitable firms [5]. Nevertheless, the extent of novelty and intricacy in innovative projects resulted in different project management methods compared to traditional projects [6]. Furthermore, innovative project risk management was one of the most challenging tasks due to its inherent ambiguities $[7,8]$. The essential risks in innovative project development and implementation involved non-viable concepts, potential products, processes, service acceptance, global project intricacies, and incomplete information [9]. Recent innovative project management studies strived to establish improved project strategies and attributes. Robust methods seemed to be a valuable alternative and offered versatility using short repetitions that enabled project adaptation through user feedback [10].

Given high project performance and effective project management, sustainable project resources proved crucial to maximizing stakeholder advantages [11]. In this vein, efficient project management enabled project success, regardless of the potential risks of 
failure [12,13]. Consequently, an accurate innovative project management strategy demonstrated to be sufficient for project goal attainment. For example, successful innovative project performance was associated with firm versatility [14] and inherent innovative project intricacies related to project cost, scope, time, and quality that explicitly influenced organizational systems [15]. The degree to which organizations were globally and accurately capable of executing innovative projects is essential for initiating and launching innovation projects [6].

When considering the internal operating system, innovation is not created by the organization itself. It is a result of decision-making by staff/employee and their implications regarding the development of new or refining goods and services. Employees' positive adoption of innovation remains vital to the smooth functioning of companies [16]. Innovation is an excellent opportunity for employees to develop and improve their expertise. It can also help them improve their managerial skills and make more risky decisions. Through an individual-level analysis, the influence of cultural values, and beliefs on innovation adoption was confirmed [17,18]. Factors such as employees' perspectives, collectivism, motivation/attitudes, and uncertainty prevention were emphasized as an accelerator of innovation adoption and, consequently, firm productivity and growth. The innovation acceptance has important ramifications for the organization. If the target group rejects it, the organization may eventually abandon the planned adoption [19].

Therefore, it is imperative that organizations thoroughly examine their interior parameters to identify the prospective benefits that can be achieved $[20,21]$ with internal elements (e.g., climate, culture, intention, and structure). Hence, organizations need to evaluate innovation readiness elements [22]. Firms tended to induce shifts, demonstrate substantial effort, combat environmental triggers, and have collaborative behavior for efficient practices when they reach a high level of organizational readiness [23-25], while others tended to avoid or resist process planning or participation, and perceive the shift unfavorably when low firm preparedness to innovate is recorded [26-28].

This study examines the readiness level for an innovative project to be adopted between partners in the context of a future cluster. In this vein, firm readiness was researched in different settings and for various innovations $[6,29,30]$. Nevertheless, research on innovative project applications and implications in food studies is still scarce. Consequently, this study provides a strategy to facilitate decision-making processes before launching an innovation project through organizational readiness level assessment. For example, project managers could assess how organizational systems encompass adequate maturity to adopt and perform particular innovative projects. Therefore, firm preparedness predictors are employed for segment identification among companies of labeled products involving the preparedness to embrace and participate in collaborative innovative projects. For instance, the study will help preserve the local product patrimony [31] by offering a new and efficient way of functioning through service clusters, ensuring a high revenue for local product producers and the sustainability of their activities as well [32]. This research further examines the association of organizational readiness with company attributes, perceived benefits of innovation, and organizational aims. By illuminating the appropriateness of organizational readiness to innovative projects, the findings provide a meaningful understanding of food-industry companies generating labeled products.

To meet the above objectives, the article is structured as follows. The second section reviews the extent of literature on organizational readiness for change, and its outcomes are discussed in adopting innovative projects within clusters. The research methodology and the results of the empirical analysis are described and discussed in the next sections. The final section outlines the conclusions, theoretical and managerial research implications, and research directions. 


\section{Theoretical Background}

\subsection{Implementing Innovative Projects within Clusters}

Innovation was typically acknowledged with multiple definitions. The Oslo Manual Guidelines [33] defined innovation as a novel or substantially enhanced product (goods or services), process, and new marketing or strategy implementation in corporate practices, professional firms, or external networking. The minimal innovation prerequisite required novel or highly improved products, processes, and marketing or organizational strategies [34]. Innovations proved successful with perpetual contributions and adaptations to organizational advancement and change [35]. Innovation is successful if it produces the ability of the company to contribute to growth through continuity and adaptation constantly. For example, companies and smaller units should be guided through intricate innovation processes (from concept creation to sale, revenue, and profit attainment) [11].

Sustainable financial development significantly relied on innovation model implementations with the innovation infrastructure as a critical determinant. The model offered robust associations between innovation topics and encouraged knowledge transfer and digital diffusion by acknowledging the potential for innovation [36]. Innovative implementation processes included an aggregate of studies, information, skills, instruments, and technologies established in project performance to fulfill the prerequisites [37]. Precise activity sequence and performance were deemed vital to identify project success or failure as the downfall led to the loss of economic resources that restricted potential organizational profitability [38].

As potential company failures increased with a high degree of innovation, project intricacy levels determined managerial strategies [39]. As such, it was deemed essential to enhance project management model versatility [38]. Innovation projects denoted a clear sample of high project intricacies as the management was significantly influenced by flexible strategy adoption for project planning [40-42]. Nevertheless, high innovative project management versatility resulted in challenging decision-making processes [43], specifically when the intricacies were associated with collective long-term ventures, such as clusters [44-46]. Porter [47] denoted clusters as a collaboration of firms, training centers, and research institutes within a specific geographical space to establish synergies around collective innovative projects. In fact, cluster-based innovation has recently gained momentum in companies $[45,48]$ and, the innovation was approachable from a general company network perspective [49]. Such networks encompassed communication and knowledge exchange between organizations considered an alternative approach to address limited resource gaps and help the company innovate and secure advantages in a highly dynamic competitive marketplace [50].

Ebers and Jarillo [51] emphasized industrial networks as a possible type to integrate various companies (firms, trade unions, and state agencies) with reiterative connections that supplied a specific market. Notably, innovative projects implied fundamental activities that grouped workers from various firms based on their motivations on resource diversification, risk alleviation, and access to complementary abilities or information transfer [45,52]. Collective projects within an innovation cluster were rarely indicated to be challenging as the main aim of clusters governance authorities served to facilitate the projects with necessary legal and economic resources and effective cooperation to ensure guarantee significant firm's innovative performance [45,53]. It is a strategic option enabling firms to be with selected relevant firms by insuring a tactical positioning and being proximate to successful actors and benefiting from cost reduction, technology transfer, and economies of scale. Within the cluster organization, a significant role is played in reinforcing and intensifying the relationships between actors to achieve predefined targets [54].

Regarding project activities, innovations needed staff commitment for implementation purposes as learning and skills enhancement were key in driving innovation practices and project attributes [55]. Given that workers needed to seek and incorporate innovative projects, certain skills were essential for information detection and construction in project establishment processes. Staff commitment towards innovative project practices was re- 
flected through organizational activity and member engagement [56]. The factors involved organizational members' perspectives or attitudes towards projects and the readiness or hesitance and intention to cooperate, despite strategy and culture variances $[57,58]$. In this respect, entrepreneurial and creative actions were essential for innovative projects during the assessment of employees' involvement to explore new business opportunities [56,59].

In fact, innovative projects have been acknowledged as the key determinant of enhancement and sustainability [36,60]. The crucial role of innovative projects in elevating organizational competency [61], resources, and profit [62] was deemed essential, thus requiring firms to be systematic and organized to enable the immediate adoption of novel innovation types. However, their adoption must be subject to a rigorous assessment to manage and reduce the risks linked to the company's external and internal environment [63].

\subsection{Organizational Readiness to Adopt Change}

\subsubsection{Definition of the Concept}

Different terms were utilized to outline change preparedness for high adherence and reluctance involving alterations. Readiness was initially presented by Lewin [64] to facilitate physical and psychological changes among organizational members. Precisely, the management needed to prove that current processes or practices were no longer applicable in the corporate context to retain or achieve success. In Kotter and Schlesinger [65], strategies for preparedness development were initiated through education, interaction, engagement, facilitation, aid, and direct or indirect compulsion. Armenakis, Harris [66] outlined change preparedness through employees' perspectives, attitudes, desires on the degree to which alterations were necessary and the firms' capability to generate effective shifts.

Notions involving discrepancy, suitability, primary aid, efficiency, and valence were subsequently determined as change preparedness dimensions [66]. Likewise, Jones, Jimmieson [67] elaborated on the definition by Armenakis, Harris [66] by involving the staff perspective through the advantages obtained from the shifts. Furthermore, Eby, Adams [68] conceptualized preparedness for shifts as a combination of novel individual interpretations and perspectives through firm preparedness to experience shifts. Holt, Armenakis [69] studied literature on readiness for change. They established a novel connotation involving the critical determinants of change preparedness as a holistic attitude impacted by content (object of alteration), process (incorporation of changes), context (situations under which shifts occurred), and people (attributes of individuals who needed to change). The factors above categorically demonstrated the degree to which individuals tended to cognitively and emotionally acknowledge, incorporate, and adopt a specific plan for deliberate status quo changes.

To date, the preparedness concept has been outlined by some scholars with various connotations involving different settings, circumstances, and individuals [70-74]. The notion referred to the preparedness measure of people, societies, firms, and countries [22,26]. Specifically, the conceptualized model corresponded to the firm preparedness level. As such, Weiner's organizational readiness for the change theory was utilized [23] to determine and assess the situational elements of firm preparedness to incorporate and involve collaborative innovative projects. Firm preparedness to change was defined as a multidimensional construct that demonstrated mutual employee resolutions to incorporate alterations and subsequent change-enabling capacities, thus reflecting employees' commitment and confidence to initiate alterations. It was denoted as organizational members' psychological and behavioral readiness towards novel practices, policies, or technology implementations [75-77].

Following Roos and Nilsson [74], firm preparedness for change relied on practiced initiatives (content), recommended strategies for initiative implementations (process), environmental characteristics of implemented initiatives (context), and individuals incorporating the initiatives (attributes). Firm preparedness was implied as the influencing factor of successful implementation and mediated intervention implementation efficiency [78,79]. Preparedness appeared to be an essential element in specific dissemination and implemen- 
tation frameworks [80]. Specifically, preparedness measures could be utilized to make correct assumptions on positive changes and empirically determine particular preparedness vulnerabilities or deficiencies [81].

\subsubsection{Organizational Readiness to Innovate}

Firm readiness to embrace innovation was defined by Scaccia, Cook [82] as the motivation for change implementations, general firm capacities, and the particular abilities needed for the desired alteration. As such, firm preparedness was defined by the degree of organizational readiness and the competency for novel conceptual implementations [83].

Essentially, organizational readiness reflects a firm's climate, motivation, culture, and capability to change through time [84,85]. In Castro and Martins [86], company climate referred to the employees' mutual perspectives, emotions, and attitudes on core firm elements which reflected the development of company's beliefs and standards and impacted personal behaviors. Similarly, McMurray and Scott [87] pinpointed the sensitiveness of employees regarding organizational climate that required improvement to eliminate participation's obstacles. This indicated the major role played by the organizational climate in preparing for the change that can be modified to better facilitate the implementation [88]. In this vein, Butterfoss, Kegler [84] aptly highlighted firm climate as an organizational mood or a novel attribute. Contrarily, firm culture was implied as the implicit operation of values, norms, and behaviors shared by employees and challenges faced [88]. From employees' perspectives, emotions, behaviors, and decision-making processes demonstrated firm culture, and were deemed crucial in obtaining strategic goals [89]. These goals will not be obtained without either balanced shared values and common aims, or an enhancement of collaboration and cohesion [90]. Finally, firm motivation dealt with the elements of inducing, navigating, and maintaining objective-based behavior, decision-making, and specific activities. Multiple theories elaborated on motivation, ranging from core instincts to self-manifestation intentions [74]. In past studies, Lehman, Greener [91] revealed that "motivational readiness" reflected the key determinant of firm preparedness for change. The construct corresponded to most psychological theories (action preceded motivation). Additionally, the self-determination theory [92] proposed that motivation was classified into various sub-constructs that distinctly forecasted human behavior. In this vein, firm motivation induced incentives or the absence of rewards in firm change implementations, thus demonstrating the belief in alterations and firm-enhancing shifts [82].

Although firm readiness has garnered much emphasis in firm change management literature $[75,82,84,93]$, research on agricultural organizations and food sectors remained scarce. Despite much research on firm preparedness involving smart technology preparedness [94], nutrition-oriented value chain [95], preparedness to incorporate halal assurance system [96], and observed staff integrity [97], innovative project implementations and implications for (segmentation reasons) in food studies were not duly regarded. More specifically, dimensions of organizational readiness for change in the labeled local products sub-sector have not yet been examined. A consistent, accurate, and comprehensive gauge of organizational readiness is needed [98], not only to evaluate or be prepared for the implementation process but also to protect the "terroir" and history of the local heritage [31,99] and assisting producers to drive more revenue by working together so that the industry cannot neither cause environment issues nor to crush the sustainability of the activity.

Although readiness was not the only efficient change implementation predictor, the essential role of readiness in the positive integration of innovative concepts and technologies in firms was evident $[82,100]$. Typically, organizational competitive advantages collectively require external resource utilization involving projects and cooperation. Therefore, innovative projects catalyzed the collaboration process, and were underlined as one of the key determinants of organizational advancement and sustainable operations [52].

As innovative project planning and performance require consideration from a holistic business point of view, evaluating organizational readiness to adopt and incorporate novel alterations is considered a vital step in the introduction and implementation 
stages $[75,82,93]$. Disregarding the viewpoint mentioned above would potentially result in different (marketing and financial) crises and low performance. As firm readiness was scarcely researched in the food industry context, the paper sought to close this loophole by addressing the following interrogations:

How influential is the firm readiness notion to innovative project implementation?

What are the notable segments among organizations based on the readiness to involve collective innovative projects in a future cluster setting?

How can the above segments differ based on their observed organizational advantages and perspectives?

Which firm preparedness dimension proved most salient in demonstrating organizational intention to adopt innovative projects collectively?

\section{Research Methodology}

\subsection{Data and Sample}

This study aimed to determine the correlation between firm readiness for change and the observed firm advantages and aims. Specifically, the study was performed on SMEs generating labeled local products under the agro-food sector. The study locations in the Kingdom of Morocco specifically targeted rural areas (product origins). Notably, 47 Geographical Indications (GI), six Origin Designation (OD), and two Agricultural Labels (AL) [101] were examined in 4 months in 2020. The primary data-gathering tool involved face-to-face and phone interviews with company owners, managers, or presidents. Respondents were requested to provide data on business and knowledgeable Organizational readiness for Change-oriented content and observed advantage assessments. Out of the initial 105 companies, 70 completed the entire process (Table A1). Since approximatively 250 firms are operating in the labeled products sub-sector, the sample was considered representative ( $28 \%$ of the total population). In line with Radhakrishna [102], the research was performed following a pretest of 10 companies in the Meknes-Fes region for error detection based on vague and irrelevant questions with multiple potential responses. The respondents' competency to address the questionnaire was also evaluated. The questionnaire was refined following the pretest.

\subsection{Construct Measurement}

A survey tool was developed. The first section exposed respondents to the study topic. For example, the research essentiality, significance, and aim were justified to alleviate potential respondent-oriented intricacies and reluctance. Matters of confidentiality, anonymity, and privacy were also clarified to ensure respondent engagement [103]. The second section encompassed notable research intricacies, such as the working definition and reason for involving collaborative innovative projects with a future cluster. Instructions to address the questions were outlined at the start of every part. The respondents were subsequently asked to respond to questions regarding their organizational climate, motivation, and culture and how they perceived benefits from innovation projects using a Likert scale in 5 points with (1) Strongly disagree and (5) Strongly agree. Meanwhile, the third section sought company profile details.

Firm preparedness was assessed with three extensive notions involving various corporate elements that must be regarded and prepared for successful shifts following the organizational development theory (firm culture, climate, and motivation) [84]. Based on specific item adaptations [84], the company culture notion was assessed with four items, while the climate and motivation counterparts were analyzed using three items each. As such, ten items were used to measure firm readiness to innovate. Observed corporate advantages were also highlighted following the potential innovative project advantages through organizational readiness. Given the context-oriented variable, the study items was based on research carried out by [104] and were subsequently adapted to the research setting. All items were confirmed and incorporated in assessing the observed advantages within the dataset of 70 companies generating labeled products. Meanwhile, 
the intention was regarded as an explicit indication of actual behavior [105]. Adapted from Bondzi-Simpson and Ayeh [104], Lada, Amin [106], three items were employed to assess organizational intention regarding collective innovative projects with a future cluster firm strategy.

\subsection{Data Analysis}

Following much scholarly emphasis on different segmentation methods, this research utilized the segmentation technique proposed by Dolnicar [107] that encompassed the explicit clustering of original scores. Notably, past studies employing original scores in segment analysis generated precise or detailed segmentation following the ability to sustain the data to a greater extent. In fact, some researchers have used different approaches which can reduce the score number to smaller factors. The original scores are not used in the segmentation, and the interpretation is based on the new scores emerging from the transformed data. [108,109]. The data assessment process encompassed two stages of segmentation algorithm: (1) organizational clustering into compatible segments following the company's preparedness dimension scores, and (2) segment-profiling against relevant variables following segment-solution authentication. A segmentation method is an explanatory data evaluation instrument to organize perceived data into genuine categories following variable combinations. Specifically, two techniques were utilized to implement the aforementioned method: hierarchical and non-hierarchical segments. The hierarchical segment approach was first employed, followed by the non-hierarchical counterpart [110]. Notably, Ward's method was first integrated with Squared Euclidean distances as an interval to examine the number of established groups and determine the organizational categories with high similarities in firm preparedness for innovative project performance based on potential labeled-products cluster. Accordingly, the consequent agglomeration schedules (stage and coefficient) and dendrogram proposed three group alternatives. Subsequent group membership and size assessment lend support for all three segments. Specifically, convergence was attained using the fourth iteration (Table A2). Hence, non-hierarchical analysis (K-Mean segmentation) was applied by defining the number of segments already obtained during the previous analysis to get the segment membership and the distance from the segment center. The iteration history generated from the analysis identified the number of iterations needed before the algorithm's convergence. The final segment centers placed the relative amplitude or the average value for the variables on a standardized scale. The ANOVA method was utilized to assess the importance of each variable. Differences among the created segments were revealed when the $p$-value was less than 0.05 , and the $F$ value exceeded the standard of 1.96. It allowed to find out variables that are significant contributors or influencers in determining the different segment membership. In addition, the discriminant analysis was performed by checking the mean, univariate ANOVA, and Box's M. The purpose was to identify differences between the segments in terms of the selected parameters and to identify how far they are variating. All the study results were presented using the SPSS software.

Comparing statistics with a theory-relevant factor (excluded in segmentation) proved essential in segment-solution profiling to comprehend organizational segments [109]. As such, organizational intentions to execute innovative projects with a future cluster were utilized. The principal component evaluation facilitated intention measure verification (Table A3). Additionally, to validate the assessment, the Kaiser-Meyer-Olkin (KMO) sampling adequacy test of 0.800 was performed. The development of one factor denoting a total variance of 76.57 percent, supported the uni-dimensionality of the scale. The internal consistency score was also fulfilled, with a value of 0.901 regarding Cronbach's alpha. Hence, the post hoc test was commonly suggested over other methods (Turkey's HSD) as the advantages were immune to unequal variances or sample sizes [111]. A one-way ANOVA was then performed to evaluate the intention of firms to execute innovative projects through service clusters. In the same vein, the segment perceived benefits were assessed by using the same approach. The KMO measure of sampling adequacy was applied $(\mathrm{KMO}=0.749)$. 
Additionally, the development of one factor implying a total variance of 68.02 percent affirmed the uni-dimensionality of the scale. The internal reliability and consistency score was also met, with a value of 0.845 regarding Cronbach's alpha.

\section{Results}

\subsection{Segment Identification}

High-correlation variables were first determined using multi-collinearity identification before implementing the segmentation method. Sarstedt and Mooi [112] indicated the necessity to omit or substitute high-correlation variables with a correlation coefficient above 0.9. In this vein, the organizational preparedness variables were evaluated for collinearity and tolerance (Table A4).

The characteristics of the segments, based on the ten firm readiness variables, are summarized in Table 1. Specifically, segment 1 reflected the smallest group with 14.2 percent of firms (Straggler). The segment seemingly included organizations at the pre-contemplation phase. Generally, organizations in this group were unwilling to collaboratively execute innovative projects with a future cluster, thus portraying minimal firm preparedness for change (eight out of 10 predictors).

Table 1. Segment description.

\begin{tabular}{|c|c|c|c|c|c|c|c|c|}
\hline \multirow[b]{2}{*}{ Firm Readiness Indicators ${ }^{2}$} & \multicolumn{2}{|c|}{$\begin{array}{l}\text { Segment } 1 \\
\text { Straggler } \\
(\mathrm{N}=10)\end{array}$} & \multicolumn{2}{|c|}{$\begin{array}{l}\text { Segment } 2 \\
\text { Interested } \\
(\mathbf{N}=47)\end{array}$} & \multicolumn{2}{|c|}{$\begin{array}{l}\text { Segment } 3 \\
\text { Reluctant } \\
(\mathrm{N}=13)\end{array}$} & \multirow[b]{2}{*}{$\mathbf{F}$} & \multirow[b]{2}{*}{ Sign. } \\
\hline & Mean & $\mathrm{SD}^{1}$ & Mean & $\mathrm{SD}^{1}$ & Mean & $\mathrm{SD}^{1}$ & & \\
\hline \multicolumn{9}{|l|}{ Organizational climate } \\
\hline $\begin{array}{l}\text { Our company staff are willing to work } \\
\text { with competitors inside the cluster to } \\
\text { implement innovative projects }\end{array}$ & 2.50 & 1.19 & 4.32 & 0.69 & 3.92 & 0.76 & 22.00 & 0.000 \\
\hline $\begin{array}{l}\text { Our employees are fully prepared to } \\
\text { acquire the necessary competencies to } \\
\text { work with competitors inside the cluster } \\
\text { to implement innovative projects }\end{array}$ & 2.80 & 0.63 & 4.36 & 0.64 & 3.84 & 0.89 & 21.60 & 0.000 \\
\hline $\begin{array}{l}\text { The leaders of the R\&D division have } \\
\text { sufficient impact on the employees to } \\
\text { guarantee that innovative projects are } \\
\text { appropriately adopted and implemented } \\
\text { within the cluster. }\end{array}$ & 2.10 & 0.87 & 3.93 & 0.82 & 3.38 & 0.77 & 21.21 & 0.000 \\
\hline \multicolumn{9}{|l|}{ Organizational culture } \\
\hline $\begin{array}{l}\text { The adoption of innovative projects with } \\
\text { competitors through the cluster fits my } \\
\text { company's image }\end{array}$ & 3.00 & 1.05 & 4.38 & 0.57 & 2.46 & 0.77 & 47.24 & 0.000 \\
\hline $\begin{array}{l}\text { Adopting innovative projects with } \\
\text { competitors through the cluster is } \\
\text { consistent with my company's outlook, } \\
\text { mission and identity. }\end{array}$ & 2.70 & 0.82 & 4.55 & 0.54 & 2.54 & 0.77 & 72.77 & 0.000 \\
\hline $\begin{array}{l}\text { Adopting innovative projects with } \\
\text { competitors through the cluster will well } \\
\text { suit my company's intended market. }\end{array}$ & 2.80 & 0.79 & 4.13 & 0.87 & 3.61 & 0.96 & 9.91 & 0.000 \\
\hline $\begin{array}{l}\text { The adoption of innovative projects with } \\
\text { competitors through the cluster fits into } \\
\text { the company's selling strategy }\end{array}$ & 2.40 & 0.96 & 4.04 & 0.86 & 2.84 & 0.90 & 19.95 & 0.000 \\
\hline
\end{tabular}


Table 1. Cont.

\begin{tabular}{|c|c|c|c|c|c|c|c|c|}
\hline \multirow[b]{2}{*}{ Firm Readiness Indicators 2} & \multicolumn{2}{|c|}{$\begin{array}{l}\text { Segment } 1 \\
\text { Straggler } \\
(\mathrm{N}=10)\end{array}$} & \multicolumn{2}{|c|}{$\begin{array}{l}\text { Segment } 2 \\
\text { Interested } \\
(\mathrm{N}=47)\end{array}$} & \multicolumn{2}{|c|}{$\begin{array}{l}\text { Segment } 3 \\
\text { Reluctant } \\
(\mathrm{N}=13)\end{array}$} & \multirow[b]{2}{*}{$\mathbf{F}$} & \multirow[b]{2}{*}{ Sign. } \\
\hline & Mean & $\mathrm{SD}^{1}$ & Mean & $\mathrm{SD}^{1}$ & Mean & $\operatorname{SD}^{1}$ & & \\
\hline \multicolumn{9}{|l|}{ Organizational motivation } \\
\hline $\begin{array}{l}\text { Our company staff are motivated to work } \\
\text { on innovative project with competitors } \\
\text { through the cluster }\end{array}$ & 2.50 & 0.53 & 4.17 & 0.81 & 3.84 & 0.89 & 17.99 & 0.000 \\
\hline $\begin{array}{l}\text { Our company staff believe in the added } \\
\text { value of innovative project made with } \\
\text { competitors through the cluster }\end{array}$ & 2.90 & 0.74 & 4.25 & 0.73 & 4.00 & 0.82 & 13.41 & 0.000 \\
\hline $\begin{array}{l}\text { Our company staff support the } \\
\text { innovative resolution made to work on } \\
\text { innovative projects with competitors } \\
\text { through the cluster }\end{array}$ & 2.90 & 0.87 & 4.21 & 0.86 & 3.84 & 0.99 & 9.19 & 0.000 \\
\hline
\end{tabular}

1: Standard deviation; ${ }^{2}$ : Likert scale in 5 point with (1) Strongly disagree and (5) Strongly agree.

Regarding firm climate in segment 1 , innovative project performance had a poor fit for employees' readiness to collaborate $(\mathrm{M}=2.50)$, master the required skills $(\mathrm{M}=2.8)$, and leadership $(M=2.10)$. Likewise, firm motivation was insufficient as the companies reflected low preparedness on general motivation $(M=2.50)$, added-value beliefs $(M=2.90)$, and innovative resolution facilitation $(\mathrm{M}=2.90)$.

The largest group was segment 2 with 67.1 percent of companies (denoted as 'Interested'). The segment demonstrated the highest level of firm preparedness. The firm climate and culture predictors fit with organizational image $(\mathrm{M}=4.38)$, outlook, mission, and identity $(\mathrm{M}=4.55)$, intended marketplace $(\mathrm{M}=4.13)$, and selling method $(\mathrm{M}=4.04)$. Additionally, the organizational members were highly prepared to adopt collaborative innovation projects $(\mathrm{M}=4.32)$ and learn the necessary skills for cooperation $(\mathrm{M}=4.36)$. Innovative project adoption also seemed to correspond to firm motivation, particularly value-added beliefs $(\mathrm{M}=4.25)$, and innovative resolution support to enable collaboration $(\mathrm{M}=4.21)$.

Segment 3 (denoted as 'Reluctant') encompassed 18.7 percent of the surveyed companies. Overall, the group of companies was neutral on most firm climate predictors, including employees' readiness to cooperate $(M=3.93)$, novel skills development $(M=3.84)$, and leadership acknowledgment with sufficient employee influence for appropriate innovative project adoption $(\mathrm{M}=3.38)$.

Multiple discriminant analysis was performed to evaluate the three-segment solution accuracy. Tables $2-4$ summarize the results. The two cumulatively-extracted discriminant functions explained the complete variance (Figure 1). For example, Wilk's Lambda and univariate $\mathrm{F}$ test revealed that the contribution of predictors to the discriminant functions was significant. Additionally, highly significant values were involved by the canonical correlation. Using the classification matrix, most cases (97.1 percent) were accurately categorized in distinct groups with high precision rates [110].

\subsection{Segment Profiling with External Variables}

4.2.1. Segment Intentions

The intention to execute collaborative innovation projects was significantly higher (on average) among segment 2 companies (Interested) compared to segment 1 counterparts (Straggler). Segment membership was used as fixed variable with intention as dependent factor to perform the one-way ANOVA. Resultantly, there was significance in Levene's test regarding variance equality $(\mathrm{F}=3.43, p=0.038)$. Welch test of means equality was employed following incongruent group sizes [111]. As shown in Table 5, the outcomes 
indicated that all three segments were adequately distinct, hence affirming the validity of segment solution.

A regression analysis was performed to justify further which of the three organizational preparedness dimensions (culture, climate, and motivation) proved most salient in driving organizational intention to execute innovative projects. Here, firm climate $(\mathrm{CR}=0.78 ; \mathrm{AVE}=0.54)$ and culture $(\mathrm{CR}=0.85 ; \mathrm{AVE}=0.60)$ were the most crucial determinants of organizational intention (Table 6).

Table 2. Standardized canonical discriminant function coefficients.

\begin{tabular}{lc}
\hline \multicolumn{1}{c}{ Indicators } & Function \\
\hline $\begin{array}{l}\text { Our company staff are willing to work with competitors inside the cluster to } \\
\text { implement innovative projects }\end{array}$ & $0.445^{*}$ \\
\hline $\begin{array}{l}\text { The adoption of innovative projects with competitors through the cluster fits } \\
\text { my company's image }\end{array}$ & $0.640 *$ \\
\hline $\begin{array}{l}\text { Adopting innovative projects with competitors through the cluster is } \\
\text { consistent with my company's outlook, mission and identity. }\end{array}$ & 0.485 * \\
\hline $\begin{array}{l}\text { Adopting innovative projects with competitors through the cluster will well } \\
\text { suit my company's intended market. }\end{array}$ & 0.407 * \\
\hline $\begin{array}{l}\text { Our company staff are motivated to work on innovative projects with } \\
\text { competitors through the cluster }\end{array}$ & 0.622 * \\
\hline
\end{tabular}

Table 3. Canonical discriminant function summary.

\begin{tabular}{lcc}
\hline Test & \multicolumn{2}{c}{ Functions at Group Centroids } \\
& $\mathbf{1}$ & $\mathbf{2}$ \\
\hline Canonical correlation & 0.892 & 0.571 \\
Eigenvalue & 3.911 & 0.485 \\
Wilk's Lambda test of functions & & \\
Wilk's Lambda value & 0.137 & 0.673 \\
Chi-square & 129.147 & 25.700 \\
DF & 10 & 4 \\
Significance & 0.000 & 0.000 \\
Segments & & \\
Straggler segment (1) & -3.330 & -1.187 \\
Interessted segment (2) & 1.337 & -0.074 \\
Reluctant segment (3) & -2.272 & 1.181 \\
\hline
\end{tabular}

Table 4. Group membership classification.

\begin{tabular}{ccccc}
\hline Segments & Cases number & $\mathbf{1}$ & $\mathbf{2}$ & $\mathbf{3}$ \\
\hline $\begin{array}{c}\text { Straggler } \\
\text { segment (1) }\end{array}$ & 10 & $9(90 \%)$ & $0(0 \%)$ & $1(10 \%)$ \\
$\begin{array}{c}\text { Interessted } \\
\text { segment (2) } \\
\text { Reluctant } \\
\text { segment (3) }\end{array}$ & 47 & $0(0 \%)$ & $47(100 \%)$ & $0(0 \%)$ \\
\hline
\end{tabular}




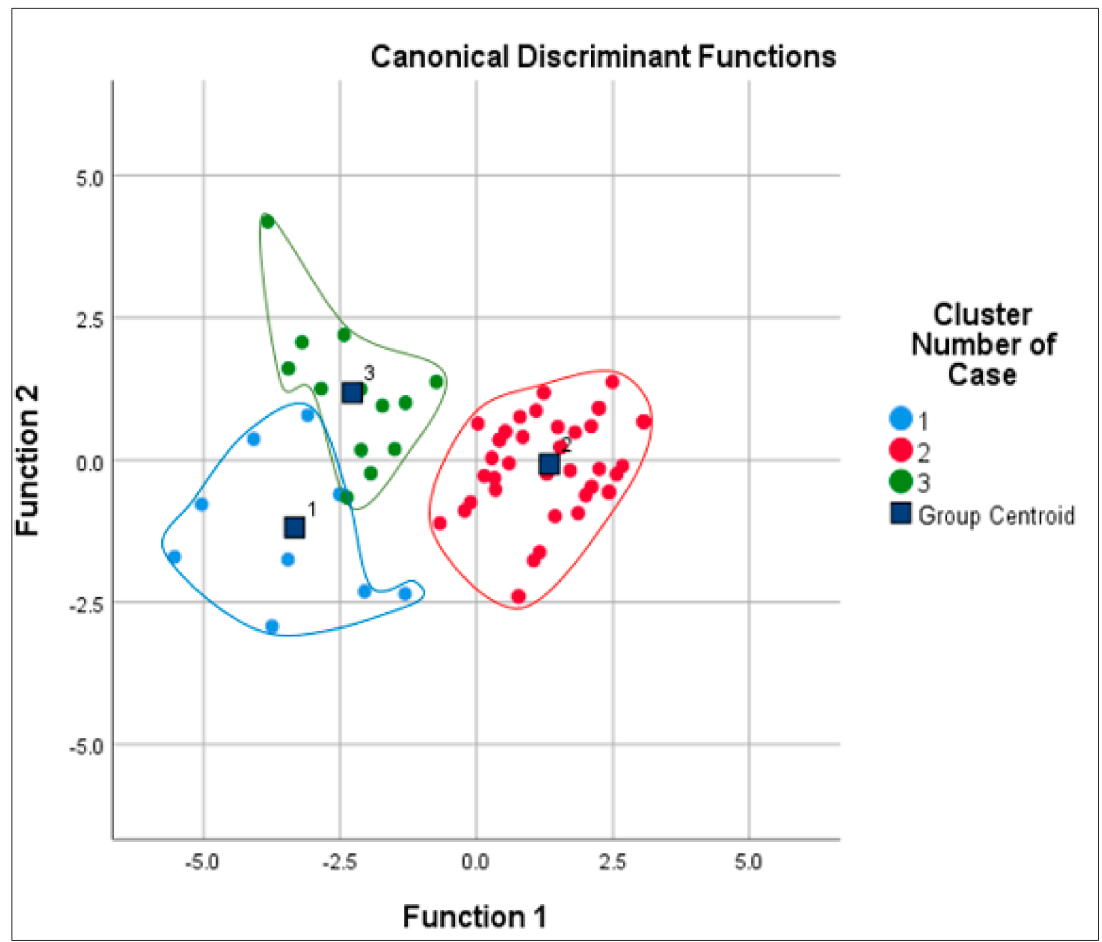

Figure 1. Canonical discriminant functions.

Table 5. Segment profiling based on firms' intentions.

\begin{tabular}{llcccccc}
\hline \multirow{2}{*}{ Variable } & Segment & N & \multicolumn{2}{c}{ Mean } & Welch Test & \multicolumn{2}{c}{$\begin{array}{c}\text { Post Hoc Test } \\
\text { Segments }\end{array}$} \\
\hline \multirow{3}{*}{ Intention } & Straggler (1) & 10 & 2.36 & 15.18 & 0 & $1 \& 2$ & 0 \\
& Interested (2) & 47 & 4.18 & & & $1 \& 3$ & 0.003 \\
& Reluctant (3) & 13 & 3.46 & & & $2 \& 3$ & 0.01 \\
\hline
\end{tabular}

Table 6. Summary of multiple regression.

\begin{tabular}{|c|c|c|c|c|c|}
\hline \multirow[b]{2}{*}{ Model } & \multicolumn{2}{|c|}{ Unstandardized Coefficients } & \multicolumn{2}{|c|}{ Standardized Coefficients } & \multirow[b]{2}{*}{ Sign. } \\
\hline & B & Error & $\beta$ & $\mathbf{t}$ & \\
\hline (Constant) & 0.374 & 0.543 & & 0.688 & \\
\hline Organizational climate & 0.444 & 0.149 & 0.378 & 2.980 & 0.004 \\
\hline Organizational culture & 0.245 & 0.09 & 0.280 & 2.486 & 0.015 \\
\hline Organizational motivation & 0.115 & 0.144 & 0.095 & 0.799 & 0.427 \\
\hline
\end{tabular}

\subsubsection{Segment Perceived Benefits}

To examine the relationship between segment membership and observed advantages, a one-way ANOVA was performed. The collinearity requirements were fulfilled by the perceived benefit predictor (Table A4). Following incongruent group sizes, Welch test of means equality was conducted based on the proposal of Field [111]. Notably, Welch's test denoted the direct benefit of disregarding unequal variances. Following Table 7, the ANOVA outcomes using the post hoc test recommended notable variances between the selected segments concerning observed corporate advantages. 
Table 7. Segment profiling based on perceived benefits.

\begin{tabular}{|c|c|c|c|c|c|c|c|}
\hline \multirow[b]{2}{*}{ Indicators } & \multirow[b]{2}{*}{ Segment } & \multirow[b]{2}{*}{$\mathbf{N}^{\mathbf{a}}$} & \multirow[b]{2}{*}{ Mean } & \multicolumn{2}{|c|}{ Welch Test } & \multicolumn{2}{|c|}{ Post Hoc Test } \\
\hline & & & & $\mathbf{F}$ & Sign. & Segments & Sign. \\
\hline Working together through & 1 & 10 & 2.60 & \multirow{3}{*}{25.80} & \multirow{3}{*}{$0.000 *$} & $1 \& 2$ & 0.000 * \\
\hline innovative projects will reduce & 2 & 47 & 4.34 & & & $1 \& 3$ & $0.027^{* *}$ \\
\hline production costs & 3 & 13 & 3.46 & & & $2 \& 3$ & $0.002 * *$ \\
\hline Working together through an & 1 & 10 & 2.90 & \multirow{3}{*}{4.92} & \multirow{3}{*}{$0.020 * *$} & $1 \& 2$ & $0.017^{* *}$ \\
\hline innovative project will increase our & 2 & 47 & 3.94 & & & $1 \& 3$ & 0.916 \\
\hline profit margin & 3 & 13 & 3.08 & & & $2 \& 3$ & $0.031 * *$ \\
\hline \multirow{3}{*}{$\begin{array}{c}\text { Participating in an innovative } \\
\text { project will improve our resources }\end{array}$} & 1 & 10 & 2.50 & \multirow{3}{*}{11.33} & \multirow{3}{*}{$0.001^{* *}$} & $1 \& 2$ & $0.000 *$ \\
\hline & 2 & 47 & 4.32 & & & $1 \& 3$ & 0.000 * \\
\hline & 3 & 13 & 3.92 & & & $2 \& 3$ & 0.251 \\
\hline
\end{tabular}

a: Cases number ; $p<0.001 ;{ }^{* *} p<0.05$.

'Interested' firms were the most positive about the advantages originating from innovative project performance. Collaborative innovation project engagement using a future cluster is believed to lead to minimized production expenditure $(\mathrm{M}=4.34)$ and increased organizational resources $(\mathrm{M}=4.32)$, and profit margins $(\mathrm{M}=3.94)$. On the contrary, the 'Straggler' segment displayed the least regard for innovative project advantages involving organizational success. For example, the smallest mean value was recorded by the straggler segment on the resource-upgrading $(\mathrm{M}=2.50)$, minimized production expenditure $(\mathrm{M}=2.60)$, and elevated profit margins $(\mathrm{M}=2.90)$. Segment 2 (Interested) also had the most positive perspectives of innovative project execution advantages using a future cluster, whereas Segment 1 (Straggler) indicated the most pessimistic viewpoints. Meanwhile, the 'Reluctant' segment was neutral on all perceived benefit predictors.

A regression analysis was performed to justify further which of the three organizational readiness dimensions (culture, climate, and motivation) were most decisive in highlighting perceived organizational advantages on innovative project execution. Thereby, firm motivation was the most crucial aspect for observed organizational advantages. Further segmentation assessments revealed that organizational intention in segment 2 was only influenced by firm culture, whereas segment 1 companies were impacted by firm climate (Table 8).

Table 8. Summary of multiple regression.

\begin{tabular}{lccccc}
\hline & \multicolumn{2}{c}{ Unstandardized Coefficients } & Standardized Coefficients & & t \\
Model & $\mathbf{B}$ & Standard Error & $\boldsymbol{\beta}$ & \multicolumn{2}{c}{ Sign. } \\
\hline (Constant) & 1.911 & 0.728 & -0.235 & -1.577 & 0.120 \\
Organizational climate & -0.315 & 0.200 & 0.037 & 0.281 & 0.780 \\
Organizational culture & 0.037 & 0.132 & 0.507 & 3.639 \\
Organizational motivation & 0.705 & 0.194 & 0.001 \\
\hline
\end{tabular}

\subsubsection{Segment General Characteristics}

All three segments were cross-tabulated based on their firm profiles (business activity age, and sub-sector) (Table 9). The Chi-square test disclosed notable segment variances involving business activity age $(p<0.05)$. Additionally, the 'Straggler' Segment was categorized using a higher percentage of organizations with experiences ranging between five and nine years. The 'Interested' Segment of organizations tended to have significantly more companies over 10 years (82.8 percent) or between five and nine years (58.3 percent). Contrarily, companies in the 'Reluctant' Segment had a higher percentage of organizations under five years (60.0 percent). In sum, segment-profiling based on organizational experience indicated that firm preparedness involving collective innovative projects might be linked to companies with much experience in the activities. In contrast, counterparts with moderate experiences tended to be fairly unprepared. 
Table 9. Segments profile.

\begin{tabular}{ccccc}
\hline Variables & $\mathbf{1}(\mathbf{\%})$ & $\begin{array}{c}\text { Segment Membership } \\
\mathbf{2 ( \% )}\end{array}$ & $\mathbf{3} \mathbf{( \% )}$ & Chi-Square Test \\
\hline Age of business & & & $0.025 p<0.05$ \\
activity & 0 & 40.0 & 60.0 & \\
$<5$ years & 22.2 & 58.3 & 19.4 & \\
$5-9$ years & 6.9 & 82.8 & 10.3 & \\
$\geq 10$ years & & & & $0.038 p<0.05$ \\
Sub-sectors & 40.0 & 34.0 & 15.4 & \\
Oil & 10.0 & 25.5 & 7.7 & \\
Arboriculture & 20.0 & 10.6 & 38.5 & \\
Date & 20.0 & 2.1 & 7.7 & \\
AMP & 10.0 & 14.9 & 0 & \\
Honey & 0 & 0 & 15.4 & \\
Milk & 0 & 2.1 & 0 & \\
Henna & 0 & 2.1 & 0 & \\
Cheese & 0 & 0 & 7.7 & \\
Semolina & 0 & 8.5 & 7.7 & \\
Spice & & & & \\
Market coverage & 33.3 & 33.3 & 33.3 & \\
Regional & 12.5 & 68.7 & 18.8 & \\
National & 15.8 & 68.4 & 15.8 & \\
International & & &
\end{tabular}

Concerning the activity sub-sector in companies, the Chi-square test determined notable segment variances. Specifically, the dominant activity in the 'Straggler' Segment was oil and date production (40.0 and 20.0 percent, respectively). Meanwhile, the activities among organizations in the 'Interested' Segment were more commonly associated with oil (34 percent), arboriculture (25.5 percent), and honey (14.7 percent). Significantly, the 'Reluctant' segment encompassed the date sub-sector (38.5 percent). As such, organizational activities that were generally unwilling to execute innovative projects (Straggler) or remained skeptical (Reluctant) encompassed the oil and date sub-sectors. The activity encompasses organized sub-sectors for companies portraying higher firm preparedness levels (arboriculture and honey).

Regarding market coverage, the Chi-square test indicated non-significant segment variances $(p>0.05)$, probably since most labeled product companies adhered to the national market. Only a few could fulfill global market requirements for export. For example, insufficient marketing method utilization and the dire necessity for public aid to penetrate novel markets were considered vital challenges.

\section{Discussion}

This research aimed to evaluate company readiness for change among small and medium-sized Moroccan organizations to execute collaborative innovation projects within a future cluster. Specifically, this study identified organizational segments and established suitable segment-profiling to provide insights into firm readiness predictors. Essentially, the study revealed the existence of three segments that distinguished organizations through the degree of willingness to execute collaborative innovation projects. The segments varied in terms of company intention and observed change advantages. Notably, firm readiness was linked to company intention. For example, Bondzi-Simpson and Ayeh [104] revealed a high correlation between firm culture and intention in serving endogenous food. The 'Interested' segment indicated the highest degree of readiness equivalent to a highest intention to adopt the change and work on innovative projects. The outcomes could be highlighted by the relevance of organizational experiences in such activities by penetrating the global market.

Furthermore, the firms could address global market needs by establishing a solid experience, such as a series of acknowledged processes and prerequisites for market positioning. 
For example, the "international" argan oil sub-sector for export, part of segment 2, was structured following multiple development project initiations by cooperative institutions and non-governmental organizations (NGOs). The latter notably facilitated the cooperative industry through a sustainable development model following the collaboration and social and economic emancipation of rural Moroccan women [113-115]. The citrus fruit industry also displayed specific benefits. The sector above benefited from notable investment incentives with extensive possibilities (free-trade agreements, market diversification opportunities, and full domestic market expansion) [116,117].

When comparing the segments, innovative projects potentially garnered substantial attention from organizational management in the 'Straggler' and 'Reluctant' Segments. Specifically, the readiness level in segment 1 (Straggler) indicated leadership gaps where firms lacked influential leaders who sufficiently can ensure the suitable adoption and implementation of innovative projects. Nevertheless, such innovative project implementations were disregarded from the organizational marketing strategies of this segment. Following organizational vulnerabilities, these firms were presently incapable of executing projects with other companies, thus hampering the possibility of taking advantage of their partners' resources and ultimately improving organizational performance. The aforementioned study outcomes corresponded to Boutriq [118], who indicated that specific enterprises generating labeled products were deterred by intricacies relevant to the employee, cooperative friction and inefficiencies. As such, market access challenges emerged following economic constraints, which presents failure risks for potential projects. On another note, segment 3 ('Reluctant') reflected moderate motivation for collective innovation project performance under the cluster. Employees perceived that projects would be essential for competency, skills enhancement, and adoption readiness. Nevertheless, firm culture indicated reluctance concerning company image and visions and missions (contrary to such project adoption strategies).

Among the three firm readiness dimensions, firm climate and culture were the most crucial factors of company intention regarding innovative project execution. Typically, firm culture indicated specific obstacles and possibilities when altering vital decision makers' methods to adopt novel projects $[119,120]$. Firm climate generally demonstrated visible and culture-embedding firm strategies to navigate organizational members' workforce [88,121]. In this respect, innovative project adoptions corresponded to worldwide organizational visions and images. Hence, the firms were motivated and prepared to collaborate with future partners and effectively serve the target market.

Concerning firm profiles, notable segment variances were indicated for business activity age and sub-sector type. Following the organizational experience, profiling implied that firm preparedness encompassing collective innovative projects might be linked to companies with high activity experience (over a decade). In contrast, those with moderate experiences tended to be highly unwilling. Consequently, the most unwilling companies to perform innovative projects (Straggler) or remained doubtful (Reluctant) were often active in the oil and date sub-sectors. Regarding companies that portrayed higher firm preparedness levels, the activity involved more organized sub-sectors, i.e., arboriculture, olive oil, and honey. Notably, these sub-sectors garnered substantial attention following Moroccan agricultural industry enhancement (Green Morocco Plan: GMP). For example, this strategy facilitated productive area improvement and the production and export of the sub-sectors mentioned above.

The GMP also emphasized the organization of farmers to execute financial-oriented activities with subsidized tools, construction, and relevant services for high agricultural solidarity in a specific period [122-124]. Likewise, the date sub-sector encompassed the Saharan and pre-Saharan region oasis ecosystem framework [125]. Despite attempts to enhance industrial productivity and incorporate farmers into formal marketing markets while organizing the individuals around cooperatives, the latter remained challenged with low competitiveness at market levels (national, regional, and global), inadequate professional organization, private investors, and a disorganized marketing chain [126,127]. Regarding 
market coverage, non-significant segment variances were identified as labeled product companies frequently targeted the national market following global market penetration intricacies [128]. Only a few companies were able to fulfill global export market prerequisites. Inadequate marketing techniques and the necessity for public facilitation to dominate novel markets caused complexities in exploring other business opportunities [129].

As expected, organizational beliefs on the advantages of collective innovation project performance reflected readiness differentiation among firms. For example, companies demonstrating higher degrees of firm preparedness tended to have optimistic perspectives of the anticipated advantages. It can be assumed that innovative project adoptions would minimize production expenditures and enhance organizational resources and profit margins. However, companies in the 'Straggler' Segment were pessimistic regarding the potential benefits of incorporating innovative projects into the mechanism. Here, motivation was the only element highlighting the observed advantages, though firm climate and culture were yet to impact organizational results.

This research offered a comprehension of firm readiness for change among companies delivering labeled products by creating homogenous segments with appropriate profiling. It provided insights related to their resolution to work with their collaborator on innovative projects through a service cluster and the perceived benefits of these projects. Therefore, it is advisable to carefully consider the results of the study, in light of the specific characteristics of the sub-sector studied and the sample size. From a practical standpoint, SMEs need to motivate their employees by setting clear goals and providing a comfortable work environment. Doing so will help them adopt and implement new ideas more easily. The SMEs managers should also ensure that they have the necessary culture and climate to meet their goals and improve their organization's performance. Project managers could assess how organizational systems encompass adequate maturity to adopt and perform particular innovative projects. This can be strengthened through various strategies such as developing a positive work environment, keeping a productive and creative workforce, adapting the firm's vision and mission to the market requirement, and improving their willingness to work with their competitors. Having a solid relationship with the public and private sectors can help an organization connect with its external network. This can also encourage the development of a culture that fosters innovation. This environment will help an organization attract and retain the best talent. Being prepared to face challenges will allow them to take advantage of the opportunities that come their way. Doing so will improve their processes and gain an advantage in the marketplace.

\section{Conclusions}

Despite the fundamental acknowledgment of firm preparedness involving company success [84,93], innovative project implementations and segmentation added-value in agro-food studies remain disregarded. This study facilitates bridging the gap by revealing that business preparedness was connected with perceived advantages and organizational intentions. Furthermore, this study contributes to the limited literature on innovative projects, specifically in less-developed regions and the labeled product sub-sector.

There are theoretical implications to the prominent role of organizational culture and climate in innovative projects. Although firm culture proved essential towards innovative advancement, work satisfaction, and company commitment $[89,120]$, focus on innovative shifts through novel collective projects remained scarce. The study outcomes verify the substantial role of the aforementioned aspects in project decision-making. They increase the need for organizational reviews through mutual values, norms, and employee behaviors and organizational mechanisms, missions, and target markets. Insights into firm readiness application regarding innovative projects in the agro-food industry could facilitate future study areas. Therefore, a particular segmentation technique was included, which still deserves more focus on agro-food albeit the rising popularity in other industries $[109,130,131]$.

The study outcomes provide valuable insights for labeled product specialists and agricultural institutions that require information on the different segments to optimize 
innovative project engagement and exploit the potential of local products for improved market positioning. Additionally, the outcomes reinforce the necessity to emphasize highly prepared firms and the possible benefits of innovative project performance while resolving latent intricacies. Beyond the financial dimension, labeled local products are factors of territorial revitalization and societal evolution, providing permanent and continuous sustainability of the activity and those distinct geographical areas [31]. The findings also demonstrate the need for campaign activities to attract the attention of individuals and facilitate less-experienced companies to avoid obstacles that might deter their operations. The mutual acknowledgment of specifically labeled product signs (origin and quality) following the joint venture between Morocco and the European Union in a convention could be a vital access route for Moroccan agricultural products into Europe [132].

The growing concern for local products (specifically in emerging nations) implies a global concern for national and local governments, industry players, and global development agencies. For example, the products needed to contribute towards social and financial enhancement (beyond the symbolic value of being a national heritage) in extensive rural populations. Innovative project performance in the food sector surpassed complexities and facilitated industrial growth. This study emphasizes the need for firms in the Laggard and Reluctant Segments to reflect upon and reconsider their unwillingness to execute innovative projects. Lastly, the outcomes underscored essential firm culture and climate functions in outlining organizational preparedness.

One research limitation relates to the emphasis on SMEs. Notably, the labeled product sub-sector primarily involved SMEs, which caused difficulties in comparing firms based on size. Nevertheless, firm preparedness across all company sizes requires extensive examination. Based on the topic sensitivity related to potential financial, environmental, and societal elements, upcoming research might investigate further settings to identify whether the outcomes are consistent in various nations and regions. As such, this research is an introduction to further research on this topic. Cross-cultural comparisons could further disclose the differentiation between the determined segments with possible cultural dimension functions (power distance, uncertainty avoidance, and pragmatism or normative orientation) [119] towards organizational preparedness development. Furthermore, additional variables in organizational (company turnover and size), managerial (professionalism and receptiveness towards change), and environmental (competitive pressure and clientele type) company settings reflected segment categorization.

Author Contributions: K.J. designed the research. K.J. and A.A. revised the methodology. K.J. and A.A. prepared for the investigation. K.J. conducted the investigation. K.J. performed main analysis. A.A. and H.D.S. validated the results. K.J. prepared the original draft. K.J.; A.A. and H.D.S. revised and edited the paper. A.A., H.D.S. and X.G. did supervision. All authors have read and agreed to the published version of the manuscript.

Funding: The study was funded by VLIR-UOS (Project number: MA2017TEA1444A103).

Institutional Review Board Statement: The study was conducted according to the guidelines of the Declaration of Helsinki.

Informed Consent Statement: Informed consent was obtained from all subjects involved in the study.

Data Availability Statement: The data are not publicly available due to restrictions of privacy.

Acknowledgments: The authors thank all the companies for their participation in the study.

Conflicts of Interest: The authors declare no conflict of interest. 


\section{Appendix A}

Table A1. Sample characteristics.

\begin{tabular}{|c|c|c|}
\hline & Frequency & Valid Percent \\
\hline \multicolumn{3}{|l|}{ Gender } \\
\hline Male & 54 & $77 \%$ \\
\hline Female & 16 & $23 \%$ \\
\hline \multicolumn{3}{|l|}{ Full-time employees } \\
\hline $10-49$ & 68 & $97 \%$ \\
\hline $50-99$ & 2 & $3 \%$ \\
\hline $100-250$ & 0 & $0 \%$ \\
\hline \multicolumn{3}{|l|}{ Age of business activity } \\
\hline$<5$ years & 5 & $7 \%$ \\
\hline $5-9$ years & 29 & $41 \%$ \\
\hline$\geq 10$ years & 36 & $51 \%$ \\
\hline \multicolumn{3}{|l|}{ Market coverage } \\
\hline Regional & 3 & $4 \%$ \\
\hline National & 48 & $69 \%$ \\
\hline International & 19 & $27 \%$ \\
\hline \multicolumn{3}{|l|}{ Turnover $^{1}$} \\
\hline Less than 10 million Dhs & 68 & $97 \%$ \\
\hline $\begin{array}{c}\text { Between } 11 \text { and } 50 \text { million } \\
\text { Dhs }\end{array}$ & 2 & $3 \%$ \\
\hline $\begin{array}{c}\text { Between } 51 \text { and } 75 \text { million } \\
\text { Dhs }\end{array}$ & 0 & $0 \%$ \\
\hline \multicolumn{3}{|l|}{ Sub-sectors } \\
\hline Oil & 22 & $31 \%$ \\
\hline Arboriculture (tree crops) & 14 & $20 \%$ \\
\hline Date & 12 & $17 \%$ \\
\hline Honey & 8 & $11 \%$ \\
\hline Spice & 5 & $7 \%$ \\
\hline $\begin{array}{l}\text { Aromatic and Medicinal Pants } \\
\text { (AMP) }\end{array}$ & 4 & $6 \%$ \\
\hline Milk & 2 & $3 \%$ \\
\hline Henna & 1 & $1 \%$ \\
\hline Cheese & 1 & $1 \%$ \\
\hline Semolina & 1 & $1 \%$ \\
\hline \multicolumn{3}{|l|}{ Label type } \\
\hline GI $=$ Geographical Indication & 55 & $79 \%$ \\
\hline $\mathrm{OD}=$ Origin Designation & 9 & $13 \%$ \\
\hline AL = Agricultural Label & 6 & $9 \%$ \\
\hline \multicolumn{3}{|l|}{ Regions } \\
\hline Drâa-Tafilalt & 16 & $23 \%$ \\
\hline Fès-Meknès & 11 & $16 \%$ \\
\hline Souss-Massa & 10 & $14 \%$ \\
\hline Oriental & 7 & $10 \%$ \\
\hline Marrakech-Safi & 6 & $9 \%$ \\
\hline Tanger-Tetouan-El hoceima & 6 & $9 \%$ \\
\hline Beni-Mellal-Khenifra & 5 & $7 \%$ \\
\hline Casablanca-Settat & 2 & $3 \%$ \\
\hline Dakhla-Oued Eddahab & 2 & $3 \%$ \\
\hline Guelmim-Oued Noun & 2 & $3 \%$ \\
\hline Lâayoune-Sakia El Hamra & 2 & $3 \%$ \\
\hline Rabat-Salé-Kenitra & 1 & $1 \%$ \\
\hline
\end{tabular}

Note: ${ }^{1}: 1$ Euro = 10.7 Dhs. 
Table A2. Measurement of iteration.

\begin{tabular}{cccc}
\hline & \multicolumn{3}{c}{ Segment Centers } \\
Current Iteration & $\mathbf{1}$ & $\mathbf{2}$ & $\mathbf{3}$ \\
\hline 1 & 3.265 & 2.204 & 3.304 \\
2 & 0.000 & 0.167 & 0.520 \\
3 & 0.000 & 0.058 & 0.198 \\
4 & 0.000 & 0.000 & 0.000 \\
\hline
\end{tabular}

Table A3. Summary item statistics to test the intention indicators.

\begin{tabular}{|c|c|c|c|c|c|c|}
\hline Validity and Reliability Tests-Intention ${ }^{2}$ & Mean & $\mathrm{SD}^{1}$ & Loading & $\begin{array}{l}\text { Corrected } \\
\text { Item-Total } \\
\text { Correlation }\end{array}$ & $\begin{array}{l}\text { Cronbach's } \\
\text { Alpha If Item } \\
\text { Deleted }\end{array}$ & $\begin{array}{l}\text { Cronbach's } \\
\text { Alpha }\end{array}$ \\
\hline $\begin{array}{l}\text { I intend to work on innovative projects with } \\
\text { partners during the first year of the creation of } \\
\text { the cluster }\end{array}$ & 3.728 & 1.153 & 0.705 & 0.720 & 0.926 & \multirow{3}{*}{0.898} \\
\hline $\begin{array}{l}\text { I'm likely to include more projects with } \\
\text { partners in my firm's strategy in the near future }\end{array}$ & 3.614 & 1.107 & 0.909 & 0.769 & 0.879 & \\
\hline $\begin{array}{l}\text { I predict that I will work on innovative projects } \\
\text { with partners within the next five years }\end{array}$ & 4.014 & 0.985 & 0.882 & 0.926 & 0.757 & \\
\hline
\end{tabular}

${ }^{1}$ : Standard deviation $;^{2}$ : Likert scale in 5 point with (1) Strongly disagree and (5) Strongly agree.

Table A4. Descriptive and collinearity statistics.

\begin{tabular}{|c|c|c|c|c|}
\hline Organizational Readiness for Change & Mean & SD & Tolerance & VIF \\
\hline \multicolumn{5}{|l|}{ Organizational Climate } \\
\hline $\begin{array}{l}\text { Our company staff are willing to work with competitors inside the } \\
\text { cluster to implement innovative projects }\end{array}$ & 3.985 & 0.999 & 0.309 & 3.241 \\
\hline $\begin{array}{l}\text { Our employees are fully prepared to acquire the necessary } \\
\text { competencies to work with competitors inside the cluster to } \\
\text { implement innovative projects }\end{array}$ & 4.042 & 0.875 & 0.269 & 3.722 \\
\hline $\begin{array}{l}\text { The leaders of the R\&D division have sufficient impact on the } \\
\text { employees to guarantee that innovative projects are appropriately } \\
\text { adopted and implemented within the cluster. }\end{array}$ & 3.571 & 1.029 & 0.489 & 2.044 \\
\hline \multicolumn{5}{|l|}{ Organizational culture } \\
\hline $\begin{array}{l}\text { The adoption of innovative projects with competitors through the } \\
\text { cluster fits my company's image }\end{array}$ & 3.828 & 1.063 & 0.367 & 2.723 \\
\hline $\begin{array}{l}\text { Adopting innovative projects with competitors through the cluster } \\
\text { is consistent with my company's outlook, mission and identity. }\end{array}$ & 3.914 & 1.113 & 0.279 & 3.586 \\
\hline $\begin{array}{l}\text { Adopting innovative projects with competitors through the cluster } \\
\text { will well suit my company's intended market. }\end{array}$ & 3.843 & 0.987 & 0.653 & 1.531 \\
\hline $\begin{array}{l}\text { The adoption of innovative projects with competitors through the } \\
\text { cluster fits into the company's selling strategy }\end{array}$ & 3.586 & 1.096 & 0.459 & 2.178 \\
\hline \multicolumn{5}{|l|}{ Organizational motivation } \\
\hline $\begin{array}{l}\text { Our company staff are motivated to work on innovative projects } \\
\text { with competitors through the cluster }\end{array}$ & 3.871 & 0.977 & 0.283 & 3.538 \\
\hline $\begin{array}{l}\text { Our company staff believe in the added value of innovative projects } \\
\text { made with competitors through the cluster }\end{array}$ & 4.014 & 0.876 & 0.296 & 3.380 \\
\hline $\begin{array}{l}\text { Our company staff support the innovative resolution made to work } \\
\text { on innovative projects with competitors through the cluster }\end{array}$ & 3.957 & 0.984 & 0.633 & 1.580 \\
\hline
\end{tabular}


Table A4. Cont.

\begin{tabular}{|c|c|c|c|c|}
\hline Organizational Readiness for Change & Mean & SD & Tolerance & VIF \\
\hline \multicolumn{5}{|l|}{ Perceived benefits variables } \\
\hline $\begin{array}{l}\text { Working together through innovative projects will reduce } \\
\text { production costs }\end{array}$ & 3.928 & 0.997 & 0.835 & 1.198 \\
\hline $\begin{array}{l}\text { Working together through innovative projects will increase our } \\
\text { profit margin }\end{array}$ & 3.628 & 1.131 & 0.856 & 1.169 \\
\hline Participating in innovative project will improve our resources & 3.986 & 0.999 & 0.736 & 1.359 \\
\hline
\end{tabular}

\section{References}

1. D'Attoma, I.; Ieva, M. Determinants of technological innovation success and failure: Does marketing innovation matter? Ind. Mark. Manag. 2020, 91, 64-81. [CrossRef]

2. Fellnhofer, K. Drivers of innovation success in sustainable businesses. J. Clean. Prod. 2017, 167, 1534-1545. [CrossRef]

3. Boly, V.; Camargo, M.; Morel, L. Ingénierie de l'Innovation/Vincent Boly, 3rd ed.; Lavoisier, Hermès: Paris, France, 2016.

4. Coiculescu, G.; Izhakian, Y.; Ravid, A.S. Innovation under Ambiguity and Risk; Baruch College Zicklin School of Business: New York, NY, USA, 2019; pp. 1-66.

5. Lichtenthaler, U. Agile Innovation: The Complementarity of Design Thinking and Lean Startup. Int. J. Serv. Sci. Manag. Eng. Technol. 2020, 11, 157-167. [CrossRef]

6. Galvez, D.; Enjolras, M.; Camargo, M.; Boly, V.; Claire, J. Firm Readiness Level for Innovation Projects: A New Decision-Making Tool for Innovation Managers. Adm. Sci. 2018, 8, 6. [CrossRef]

7. Batkovskiy, A.M.; Konovalova, A.V.; Semenova, E.G.; Trofimets, V.Y.; Fomina, A.V. Risks of Development and Implementation of Innovative Projects. Mediterr. J. Soc. Sci. 2015, 6, 243-253. [CrossRef]

8. Klakegg, O. Project Risk Management: Challenge Established Practice. Adm. Sci. 2016, 6, 21. [CrossRef]

9. Morel, L.; Camargo, M.; Boly, V. Comment réusir le pilotage d'un projet d'innovation dans une PME/PMI. In Le Grand Livre de L'économie PME; Gilles, L., Ed.; Gualino-Lextenso Éditions; Gualino-Lextenso: Paris, France, 2015.

10. Schulz, J.; Steinhoff, F.; Jepsen, K. Strike while the iron is hot: User centricity adapted to the agile innovation development process. In Strategy and Communication for Innovation, 3rd ed.; Pfeffermann, N., Minshall, T., Mortara, L., Eds.; Springer: New York, NY, USA, 2017.

11. Stosic, B.; Milutinović, R. Key issues to improve innovation project excellence. In Key Issues for Management of Innovative Projects; Llamas, B., Mazadiego, F.L., Eds.; IntechOpen: London, UK, 2017; pp. 25-43.

12. Radujković, M.; Sjekavica, M. Project Management Success Factors. Procedia Eng. 2017, 196, 607-615. [CrossRef]

13. Serrador, P.; Turner, R. The Relationship between Project Success and Project Efficiency. Proj. Manag. J. 2015, 46, 30-39. [CrossRef]

14. Christiansen, J.; Gasparin, M. Managing Controversies in the Fuzzy Front End: Managing Controversies in the Fuzzy Front End. Creat. Innov. Manag. 2016, 25, 500-514. [CrossRef]

15. Liu, H.; Liu, Z.; Lai, Y.; Li, L. Factors Influencing Collaborative Innovation Project Performance: The Case of China. Sustainability 2021, 13, 7380. [CrossRef]

16. Ober, J. Innovation Adoption: Empirical Analysis on the Example of Selected Factors of Organizational Culture in the IT Industry in Poland. Sustainability 2020, 12, 8630. [CrossRef]

17. Sun, S.; Lee, P.C.; Law, R.; Zhong, L. The impact of cultural values on the acceptance of hotel technology adoption from the perspective of hotel employees. J. Hosp. Tour. Manag. 2020, 44, 61-69. [CrossRef]

18. Wisdom, J.P.; Chor, K.H.B.; Hoagwood, K.E.; Horwitz, S.M. Innovation Adoption: A Review of Theories and Constructs. Adm. Policy Ment. Health Ment. Health Serv. Res. 2014, 41, 480-502. [CrossRef]

19. Frambach, R.T.; Schillewaert, N. Organizational innovation adoption: A multi-level framework of determinants and opportunities for future research. J. Bus. Res. 2002, 55, 163-176. [CrossRef]

20. Panuwatwanich, K.; Stewart, R.A. Evaluating innovation diffusion readiness among architectural and engineering design firms: Empirical evidence from Australia. Autom. Constr. 2012, 27, 50-59. [CrossRef]

21. Valitov, S.M.; Khakimov, A.K. Innovative Potential as a Framework of Innovative Strategy for Enterprise Development. Procedia Econ. Financ. 2015, 24, 716-721. [CrossRef]

22. Akunyumu, S.; Fugar, F.D.; Adinyira, E.; Danku, J.C. A review of models for assessing readiness of construction organisations to innovate. Constr. Innov. 2020, 21, 279-299. [CrossRef]

23. Weiner, B.J. A theory of organizational readiness for change. Implement. Sci. 2009, 4, 67. [CrossRef]

24. Çetinkaya, A.Ş.; Niavand, A.; Rashid, M. Organizational change and competitive advantage: Business size matters. Bus. Manag. Stud. Int. J. 2019, 7, 40-67. [CrossRef]

25. Timmor, Y.; Zif, J. Change readiness: An alternative conceptualization and an exploratory investigation. EuroMed J. Bus. 2010, 5, 138-165. [CrossRef] 
26. Shea, C.M.; Jacobs, S.R.; Esserman, D.A.; Bruce, K.; Weiner, B.J. Organizational readiness for implementing change: A psychometric assessment of a new measure. Implement. Sci. 2014, 9, 1-15. [CrossRef] [PubMed]

27. Thakur, R.; Srivastava, S. From Resistance to Readiness: Role of Mediating Variables. J. Organ. Change Manag. 2018, 31, $230-247$. [CrossRef]

28. Abdel-Ghany, M.M.M. Readiness for change, change beliefs and resistance to change of extension personnel in the New Valley Governorate about mobile extension. Ann. Agric. Sci. 2014, 59, 297-303. [CrossRef]

29. Hamilton, S.; McLaren, S.; Mulhall, A. Assessing organisational readiness for change: Use of diagnostic analysis prior to the implementation of a multidisciplinary assessment for acute stroke care. Implement. Sci. 2007, 2, 21. [CrossRef]

30. Weber, P.; Weber, J. Changes in Employee Perceptions during Organizational Change. Leadersh. Organ. Dev. J. 2001, 22, 291-300. [CrossRef]

31. Prévost, P.; Capitaine, M.; Gautier-Pelissier, F.; Michelin, Y.; Jeanneaux, P.; Fort, F.; Javelle, A.; Moïti-Maïzi, P.; Lériche, F.; Brunschwig, G.; et al. Le terroir, un concept pour l'action dans le développement des territoires. VertigO 2014, 14, 1-20. [CrossRef]

32. Ouboutaib, E.F.; Aitheda, A.; Mekkaoui, S. L'authenticité durable: Un mixage paradoxal ou complémentaire? Cas des produits de terroir des coopératives de la région Souss Massa, Maroc. Rev. Repères Perspect. Econ. 2020, 4, 372-384.

33. OECD. Oslo Manual: Guidelines for Collecting and Interpreting Innovation Data, 3rd ed.; The Measurement of Scientific and Technological Activities; OECD Publishing: Paris, France, 2005.

34. Ramadani, V.; Hisrich, R.D.; Abazi-Alili, H.; Dana, L.P.; Panthi, L.; Abazi-Bexheti, L. Product innovation and firm performance in transition economies: A multi-stage estimation approach. Technol. Forecast. Soc. Change 2019, 140, 271-280. [CrossRef]

35. Sartori, R.; Costantini, A.; Ceschi, A.; Tommasi, F. How Do You Manage Change in Organizations? Training, Development, Innovation, and Their Relationships. Front. Psychol. 2018, 9, 1-11. [CrossRef]

36. Petryna, M.; Stavnycha, N.; Tarayevska, L.; Rishchuk, L.; Kushlyk, O. A methodological approach to the evaluation of the effectiveness of innovative projects. In Proceedings of the The International Conference on Sustainable Futures: Environmental, Technological, Social and Economic Matters (ICSF 2020), Kryvyi Rih, Ukraine, 20-22 May 2020; Volume 166, pp. 1-7.

37. Project-Management-Institute. Guide to the Project Management Body of Knowledge (PMBOK Guide); Project Management Institute: Newton Square, PA, USA, 2017; p. 592.

38. Eriksson, P.E.; Larsson, J.; Pesämaa, O. Managing complex projects in the infrastructure sector-A structural equation model for flexibility-focused project management. Int. J. Proj. Manag. 2017, 35, 1512-1523. [CrossRef]

39. Garcia-Quevedo, J.; Segarra-Blasco, A.; Teruel, M. Financial constraints and the failure of innovation projects. Technol. Forecast. Soc. Change 2018, 127, 127-140. [CrossRef]

40. Candi, M.; Van Den Ende, J.; Gemser, G. Organizing innovation projects under technological turbulence. Technovation 2013, 33, 133-141. [CrossRef]

41. San Cristóbal, J.R.; Carral, L.; Diaz, E.; Fraguela, J.A.; Iglesias, G. Complexity and Project Management: A General Overview. Complexity 2018, 2018, 1-11. [CrossRef]

42. Ruoslahti, H. Complexity in project co-creation of knowledge for innovation. J. Innov. Knowl. 2020, 5, 228-235. [CrossRef]

43. Parizotto, L.; Tonso, A.; Carvalho, M. The challenges of project management in small and medium-sized enterprises: A literature review based on bibliometric software and content analysis. Gestão Produção 2020, 27, 1-23.

44. Dietrich, P.; Eskerod, P.; Dalcher, D.; Sandhawalia, B. The Dynamics of Collaboration in Multipartner Projects. Proj. Manag. J. 2010, 41, 59-78. [CrossRef]

45. Calamel, L.; Defélix, C.; Picq, T.; Retour, D. Inter-organisational projects in French innovation clusters: The construction of collaboration. Int. J. Proj. Manag. 2012, 30, 48-59. [CrossRef]

46. Chen, X.; Wang, E.; Miao, C.; Ji, L.; Pan, S. Industrial Clusters as Drivers of Sustainable Regional Economic Development? An Analysis of an Automotive Cluster from the Perspective of Firms' Role. Sustainability 2020, 12, 2848. [CrossRef]

47. Porter, M. Clusters and the new economics of competition. Harv. Bus. Rev. 1998, 76, 77-90. [PubMed]

48. Ferras-Hernandez, X.; Nylund, P. Clusters as Innovation Engines: The Accelerating Strengths of Proximity. Eur. Manag. Rev. 2018, 16, 1-27. [CrossRef]

49. Gulati, R.; Nohria, N.; Zaheer, A. Strategic networks. Strategic Manag. J. 2000, 21, 203-215. [CrossRef]

50. Bittencourt, B.A.; Galuk, M.B.; Daniel, V.M.; Zen, A.C. Cluster Innovation Capability: A systematic review. Int. J. Innov. 2019, 7, 26-44. [CrossRef]

51. Ebers, M.; Jarillo, J.C. Preface: The Construction, Forms, and Consequences of Industry Networks. Int. Stud. Manag. Organ. 1997, 27, 3-21. [CrossRef]

52. Chuluun, T.; Prevost, A.; Upadhyay, A. Firm network structure and innovation. J. Corp. Financ. 2017, 44, 193-214. [CrossRef]

53. Hervas-Oliver, J.L.; Sempere-Ripoll, F.; Rojas Alvarado, R.; Estelles-Miguel, S. Agglomerations and firm performance: Who benefits and how much? Reg. Stud. 2018, 52, 338-349. [CrossRef]

54. Morgulis-Yakushev, S.; Sölvell, Ö. Enhancing dynamism in clusters: A model for evaluating cluster organizations' bridge-building activities across cluster gaps. Compet. Rev. Int. Bus. J. 2017, 27, 98-112.

55. Salisu, Y.; Julienti, L.; Bakar, A. Employee Commitment to Change, Innovation Strategy and the Performance of Small and Medium Enterprises. Int. J. Bus. Technopreneurship 2019, 9, 123-140.

56. Skowron-Grabowska, B.; Nowakowska-Grunt, J. Innovative Projects in Enterprises. Sci. Pap. Sil. Univ. Technol. Organ. Manag. Ser. 2017, 2017, 97-111. [CrossRef] 
57. Dameron, S.; Joffre, O. The good and the bad: The impact of diversity management on co-operative relationships. Int. J. Hum. Resour. Manag. 2007, 18, 2037-2056. [CrossRef]

58. Golini, R.; Kalchschmidt, M.; Landoni, P. Adoption of project management practices: The impact on international development projects of non-governmental organizations. Int. J. Project Manag. 2015, 33, 1-40. [CrossRef]

59. Kang, T.W.; Sinha, P.N.; Park, C.I.; Lee, Y.K. Exploring the Intra Entrepreneurship-Employee Engagement-Creativity Linkage and the Diverse Effects of Gender and Marital Status. Front. Psychol. 2021, 12, 1-15. [CrossRef]

60. Holt, D.; Daspit, J. Diagnosing Innovation Readiness in Family Firms. Calif. Manag. Rev. 2015, 58, 82-96. [CrossRef]

61. Pierre, A.; Fernandez, A.-S. Going Deeper into SMEs' Innovation Capacity: An Empirical Exploration of Innovation Capacity Factors. J. Innov. Econ. Manag. 2018, 25, 139-181. [CrossRef]

62. Giménez, J.; Madrid-Guijarro, A.; Duréndez, A. Competitive Capabilities for the Innovation and Performance of Spanish Construction Companies. Sustainability 2019, 11, 5475. [CrossRef]

63. Sag, S.; Sezen, B.; Güzel, M. Factors That Motivate or Prevent Adoption of Open Innovation by SMEs in Developing Countries and Policy Suggestions. Procedia Soc. Behav. Sci. 2016, 235, 756-763. [CrossRef]

64. Lewin, K. Frontiers in group dynamics: Concept, method and reality in social science; social equilibria and social change. Hum. Relat. 1947, 1, 5-41. [CrossRef]

65. Kotter, J.P.; Schlesinger, L.A. Choosing strategies for change. Harv. Bus. Rev. 1989, 57, 451-459.

66. Armenakis, A.; Harris, S.; Mossholder, K. Creating Readiness for Organizational Change. Hum. Relat. 1993, 46, 681-704. [CrossRef]

67. Jones, R.; Jimmieson, N.; Griffiths, A. The Impact of Organizational Culture and Reshaping Capabilities on Change Implementation Success: The Mediating Role of Readiness for Change. J. Manag. Stud. 2005, 42, 361-386. [CrossRef]

68. Eby, L.T.; Adams, D.M.; Russell, J.E.; Gaby, S.H. Perceptions of Organizational Readiness for Change: Factors Related to Employees' Reactions to the Implementation of Team-Based Selling. Hum. Relat. 2000, 53, 419-442. [CrossRef]

69. Holt, D.T.; Armenakis, A.A.; Feild, H.S.; Harris, S.G. Readiness for Organizational Change: The Systematic Development of a Scale. J. Appl. Behav. Sci. 2007, 43, 232-255. [CrossRef]

70. Tran, Q.; Huang, D.; Liu, B.; Ekram, H.M. A Construction Enterprise's Readiness Level in Implementing E-Procurement: A System Engineering Assessment Model. Syst. Eng. Procedia 2011, 2, 131-141. [CrossRef]

71. Uzkurt, C.; Kumar, R.; Ensari, N. Assessing organizational readiness for innovation: An exploratory study on organizational characteristics of innovativeness. Int. J. Innov. Technol. Manag. 2013, 10, 1-26. [CrossRef]

72. Barham, H. Development of a Readiness Assessment Model for Evaluating Big Data Projects: Case Study of Smart City in Oregon, USA. Ph.D. Thesis, Portland State University, Portland, OR, USA, 2019.

73. Errida, A.; Lotfi, B. Measuring Change Readiness for Implementing a Project Management Methodology an Action Research Study. Acad. Strateg. Manag. J. 2020, 19, 1-17.

74. Roos, J.; Nilsson, V. Driving Organizational Readiness for Change through Strategic Workshops. Int. J. Manag. Appl. Res. 2020, 7, 1-28. [CrossRef]

75. Weiner, B.J. A theory of organizational readiness for change. In Handbook on Implementation Science; Nilsen, P., Birken, S.A., Eds.; Edward Elgar Publishing: Cheltenham, UK, 2020; pp. 215-232.

76. Rafferty, A.E.; Minbashian, A. Cognitive beliefs and positive emotions about change: Relationships with employee change readiness and change-supportive behaviors. Hum. Relat. 2019, 72, 1623-1650. [CrossRef]

77. Haqq, Z.N.; Natsir, M. Three Components of Readiness to Change: Communication of Change and Change-Efficacy as Antecendents. Perisai Islamic Bank. Financ. J. 2019, 3, 12. [CrossRef]

78. Holt, D.T.; Helfrich, C.D.; Hall, C.G.; Weiner, B.J. Are you ready? How health professionals can comprehensively conceptualize readiness for change. J. Gen. Intern. Med. 2010, 25, 50-55. [CrossRef]

79. Bendi, D.; Rana, M.Q.; Arif, M.; Goulding, J.S.; Kaushik, A.K. Understanding off-site readiness in Indian construction organisations Constr. Innov. 2020, 21, 105-122. [CrossRef]

80. Meyers, D.; Durlak, J.; Wandersman, A. The Quality Implementation Framework: A Synthesis of Critical Steps in the Implementation Process. Am. J. Community Psychol. 2012, 50, 462-480. [CrossRef]

81. Helfrich, C.D.; Kohn, M.J.; Stapleton, A.; Allen, C.L.; Hammerback, K.E.; Chan, K.C.; Parrish, A.T.; Ryan, D.E.; Weiner, B.J.; Harris, J.R.; et al. Readiness to Change Over Time: Change Commitment and Change Efficacy in a Workplace Health-Promotion Trial. Front. Public Health 2018, 6, 1-9. [CrossRef]

82. Scaccia, J.P.; Cook, B.S.; Lamont, A.; Wandersman, A.; Castellow, J.; Katz, J.; Beidas, R.S. A practical implementation science heuristic for organizational readiness: $\mathrm{R}=\mathrm{MC}(2)$. J. Community Psychol. 2015, 43, 484-501. [CrossRef]

83. Piotrowska-Bożek, W. Organizational readiness for change: Toward understanding its nature and dimensions. Zesz. Nauk. Wyższej Szkoły Humanit. Zarządzanie 2019, 20, 227-238. [CrossRef]

84. Butterfoss, F.D.; Kegler, M.C.; Francisco, V.T. Mobilizing organizations for health promotion: Theories of organizational change. In Health Behavior and Health Education: Theory, Research, and Practice, 4th ed.; Glanz, K., Rimer, B.K., Viswanath, K., Eds.; Jossey-Bass: San Francisco, CA, USA, 2008; pp. 335-361.

85. Domlyn, A.M.; Wandersman, A. Community coalition readiness for implementing something new: Using a Delphi methodology. J. Community Psychol. 2019, 47, 882-897. [CrossRef] 
86. Castro, M.; Martins, N. The relationship between organisational climate and employee satisfaction in a South African information and technology organisation. S. Afr. J. Ind. Psychol. 2010, 36, 1-9. [CrossRef]

87. McMurray, A.; Scott, D. Determinants of organisational climate for academia. High. Educ. Res. Dev. 2013, 32,960-974. [CrossRef]

88. Schneider, B.; Ehrhart, M.; Macey, W. Organizational Climate and Culture. Annu. Rev. Psychol. 2013, 64, 361-388. [CrossRef]

89. Lok, P.; Crawford, J.D. The effect of organisational culture and leadership style on job satisfaction and organisational commitment: A cross-national comparison. J. Manag. Dev. 2004, 23, 321-338. [CrossRef]

90. Lone, J.A.; Garnås, A.; Myklebust, T.; Bjørklund, R.; Hoff, T.; Bjørkli, C. Organizational climate and investigation performance in the Norwegian police: A qualitative study. J. Investig. Psychol. Offender Profiling 2017, 14, 227-245. [CrossRef]

91. Lehman, W.E.K.; Greener, J.M.; Simpson, D.D. Assessing Organizational Readiness for Change. J. Subst. Abus. Treat. 2002, 22, 197-209. [CrossRef]

92. Deci, E.; Ryan, R. Intrinsic Motivation and Self-Determination in Human Behavior; Perspectives in Social Psychology; Springer: Boston, MA, USA, 1985; Volume 16, p. 372.

93. Burnett, S.; Benn, J.; Pinto, A.; Parand, A.; Iskander, S.; Vincent, C. Organisational readiness: Exploring the preconditions for success in organisation-wide patient safety improvement programmes. BMJ Qual. Saf. 2010, 19, 313-317. [CrossRef]

94. Facchini, F.; Digiesi, S.; Mossa, G.; Mummolo, G. Evaluating the I4.0 transformation readiness of agri-food companies: From factories to 'smart' factories. In Proceedings of the XXIII Summer School "Francesco Turco"-Industrial Systems Engineering, Palermo, Italy, 12-14 September 2018; pp. 12-14.

95. Wesana, J.; De Steur, H.; Dora, M.K.; Mutenyo, E.; Muyama, L.; Gellynck, X. Towards nutrition sensitive agriculture. Actor readiness to reduce food and nutrient losses or wastes along the dairy value chain in Uganda. J. Clean. Prod. 2018, 182, 46-56. [CrossRef]

96. Abd Rahman, A.; Singhry, H.B.; Hanafiah, M.H.; Abdul, M. Influence of perceived benefits and traceability system on the readiness for Halal Assurance System implementation among food manufacturers. Food Control 2017, 73, 1318-1326. [CrossRef]

97. Xu, X.V.; Payne, S. Individual difference predictors of perceived change fairness. J. Manag. Psychol. 2016, 31, 133-139. [CrossRef]

98. Walker, T.J.; Brandt, H.M.; Wandersman, A.; Scaccia, J.; Lamont, A.; Workman, L.; Dias, E.; Diamond, P.M.; Craig, D.W.; Fernandez, M.E. Development of a comprehensive measure of organizational readiness (motivation $\times$ capacity) for implementation: A study protocol. Implement. Sci. Commun. 2020, 1, 103. [CrossRef]

99. Ackermann, N. Les consortiums de valorisation de produits de terroir: Une clé pour la valorisation inclusive et durable des produits typiques avec indication géographique. In Proceedings of the Colloque Mondial sur les Indications Géographiques, Lima, Peru, 22-24 June 2011; pp. 1-10.

100. Powell, B.J.; McMillen, J.C.; Proctor, E.K.; Carpenter, C.R.; Griffey, R.T.; Bunger, A.C.; Glass, J.E.; York, J.L. A compilation of strategies for implementing clinical innovations in health and mental health. Med. Care Res. Rev. 2012, 69, 123-157. [CrossRef]

101. MAPM-DREF. Produits Agricoles Labellisés au Maroc; Ministère de l'Agriculture et de la Pêche Maritime, du Développement Rural et des Eaux et Forêts: Rabat, Morocco, 2019; p. 99.

102. Radhakrishna, R.B. Tips for developing and testing questionnaires/instruments. J. Ext. 2007, 45, 1-4.

103. Francis, J.; Eccles, M.P.; Johnston, M.; Walker, A.E.; Grimshaw, J.M.; Foy, R.; Kaner, E.F.; Smith, L.; Bonetti, D. Constructing Questionnaires Based on the Theory of Planned Behaviour: A Manual for Health Services Researchers, Quality of Life and Management of Living Resources; Centre for Health Services Research: Newcastle upon Tyne, UK, 2004.

104. Bondzi-Simpson, A.; Ayeh, J. Assessing hotel readiness to offer local cuisines: A clustering approach. Int. J. Contemp. Hosp. Manag. 2019, 31, 998-1020. [CrossRef]

105. Alt, J.K.; Lieberman, S. Modeling the theory of planned behavior from survey data for action choice in social simulations. In Proceedings of the 19th Conference on Behavior Representation in Modeling and Simulation, Charleston, SC, USA, 22-25 March 2010.

106. Lada, S.; Amin, H.; Tanakinjal, G. Predicting intention to choose halal products using theory of reasoned action. Int. J. Islamic Middle East. Financ. Manag. 2009, 2, 66-76. [CrossRef]

107. Dolnicar, S. Market segmentation in tourism. In Tourism Management: Analysis, Behaviour and Strategy; Woodside, A.G., Martin, D., Eds.; CAB International: Cambridge, UK, 2008.

108. Dolnicar, S. A Review of Data-Driven Market Segmentation in Tourism. J. Travel Tour. Mark. 2002, 12, 1-22. [CrossRef]

109. Prayag, G.; Hosany, S. When Middle East meets West: Understanding the motives and perceptions of young tourists from United Arab Emirates. Tour. Manag. 2014, 40, 35-45. [CrossRef]

110. Hair, J.F.; Black, W.C.; Babin, B.J.; Anderson, R.E. Multivariate Data Analysis: A Global Perspective, 7th ed.; Pearson Education: Upper Saddle River, NJ, USA, 2010; p. 800.

111. Field, A. Discovering Statistics Using SPSS, 4th ed.; SAGE Publications Ltd.: London, UK, $2013 ;$ pp. 1-952.

112. Sarstedt, M.; Mooi, E. A Concise Guide to Market Research: The Process, Data, and Methods Using IBM SPSS Statistics, 2nd ed.; Springer Texts in Business and Economics; Springer: Berlin, Germany, 2014; Volume 22, p. 347.

113. Chakib, A. Rapport Final de Mission: Projet de recherche filière Argan: Programme Gouvernance des Entreprises et Organisations du Développement Durable; SalvaTerra: Paris, France, 2013; p. 38.

114. Chaussod, R.; Adlouni, A.; Christon, R. L'arganier et l'huile d'argane au Maroc: Vers la mutation d'un système agroforestier traditionnel? Enjeux et contribution de la recherche. Cah. Agric. 2005, 14, 351-356.

115. Faouzi, H. L'arganeraie marocaine, un système traditionnel face aux mutations récentes: Le cas du territoire des Haha, Haut Atlas occidental. Norois 2017, 242, 57-81. [CrossRef] 
116. DEPF. Performances et Compétitivité des Exportations des Filières Phares du Secteur Agroalimentaire Marocain; Direction des Etudes et des Prévisions Financières: Rabat, Morocco, 2014; p. 36.

117. MAPM. Note de Veille Secteur Agrumicole; Direction de la Stratégie et des Statistiques: Rabat, Morocco, $2013 ;$ p. 20.

118. Boutriq, I. Contribution à L'analyse des Compétences Clés des Groupements d'Intérêt Economique Oléicoles de la Région de Fès-Meknès, in Ingénieurie de Développement Rural; Ecole Nationale d'Agriculture de Meknès: Meknes, Morocco, 2020; p. 113.

119. Hofstede, G.H.; Hofstede, G.J.; Minkov, M. Cultures and Organizations: Software of the Mind, 3rd ed.; McGraw-Hill Education: New York, NY, USA, 2010; p. 576.

120. Rahimi, R. Customer relationship management (people, process and technology) and organisational culture in hotels: Which traits matter? Int. J. Contemp. Hosp. Manag. 2017, 29, 1380-1402. [CrossRef]

121. Saleem, M.; Perveen, N. Organizational climate and its impact on firm financial performance. J. Hum. Resour. Manag. 2019, 1, 47-60.

122. Moujanni, A.; Essamadi, A.; Terrab, A. L'apiculture au Maroc: Focus sur la production de miel. Int. J. Innov. Appl. Stud. 2017, 20, $52-78$.

123. MAPM. Veille économique Secteur Amandier; Direction de la stratégie et des statistiques: Morocco, Rabat, $2014 ;$ p. 11.

124. MAPM. Directives Stratégiques pour la Filière Phoénicicole; Direction de la stratégie et des statistiques: Morocco, Rabat, $2015 ;$ p. 15.

125. Michon, G. Les oasis en Afrique du Nord: Dynamiques territoriales et durabilité des systèmes de production agricole. Cahiers Agric. 2017, 26, 1-2.

126. CBD. Appui des Groupements D'intérêt Économique pour le Développement de la Filière Phoenicicole au Niveau des Oasis Marocains; Ministère de l'agriculture et de la pêche maritime: Rabat, Morocco, 2015; p. 128.

127. Sadiki, M.; Essami, A.; Bouaouinate, A. Les produits de terroir de la région de tafilalet: Entre la diversité et l'extinction. J. Political Orbits 2019, 3, 95-112.

128. Ahrouch, S.; Choukri, M.; Rhabra, S.; Erramy, K. Produits de terroir au service du développement durable dans la région Souss-Massa: Cas de l'union des coopératives des femmes d'Argane Tissaliwine. Moroc. J. Bus. Stud. 2017, 1, $209-232$.

129. Bennani, B. Marketing, quelle place dans la gestion des coopératives au Maroc: Cas des coopératives de la région Tensift-Haouz. Rev. Maroc. Rech. Manag. Mark. 2013, 8, 171-183.

130. Amaro, S.; Duarte, P.; Henriques, C. Travelers' use of social media: A clustering approach. Ann. Tour. Res. 2016, 59, 1-15. [CrossRef]

131. Dolnicar, S.; Kaiser, S.; Lazarevski, K.; Leisch, F. Biclustering: Overcoming Data Dimensionality Problems in Market Segmentation. J. Travel Res. 2012, 51, 41-49. [CrossRef]

132. El Hadad-Gauthier, F. Indications géographiques et négociations d'accords bilatéraux: Cas de l'accord Maroc-UE. In Proceedings of the 4ème Séminaire d'Antalya sur les Indications Géographiques, Antalya, Turkey, 27-28 October 2016. 